\title{
Late Diagnosed Argininemia
}

\begin{tabular}{|c|c|c|}
\hline Author(s) & \multicolumn{2}{|c|}{ 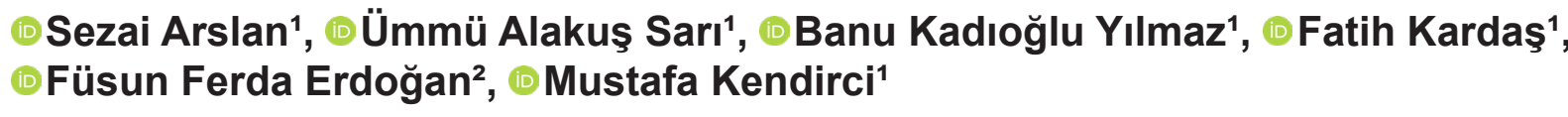 } \\
\hline Affiliation(s) & \multicolumn{2}{|c|}{$\begin{array}{l}\text { 1Erciyes University Faculty of Medicine, Division of Pediatric Nutrition and Metabolic Diseases, Kayseri, Turkey } \\
{ }^{2} \text { Erciyes University Faculty of Medicine, Department of Neurology, Kayseri, Turkey }\end{array}$} \\
\hline $\begin{array}{l}\text { Article } \\
\text { Information }\end{array}$ & $\begin{array}{l}\text { Article Type: Case Report } \\
\text { Article Group: Genetics \& Metabolism }\end{array}$ & $\begin{array}{l}\text { Received: } 28.01 .2021 \\
\text { Accepted: } 23.03 .2021 \\
\text { Available Online: } 30.04 .2021\end{array}$ \\
\hline
\end{tabular}

Cite this article as: Arslan S, Sarı UA, YIImaz BK, Kardas F, Erdogan FF, Kendirci M. Late Diagnosed Argininemia. J Pediatr Acad 2021; 2: 39-42.

\section{Abstract}

Ammonia; It is a toxic molecule for the central nervous system resulting from the catabolism of proteins. Its excretion is provided with the urea cycle. Argininemia is a rare subtype of urea cycle disorders. Arginase enzyme catalyzes the last stage of the urea cycle, arginine; urea and ornithine are broken down. The decrease in arginase 1 (ARG1) enzyme activity is responsible for argininemia. The most common presenting symptoms of patients diagnosed with argininemia are progressive spastic diplegia, regression in developmental stages, choreoathetosis, hepatomegaly and seizures. The diagnosis of the disease can be made by detecting the elevation of arginine in body fluids together with the increase in serum ammonia. Neurological findings of these patients can be confused with cerebral palsy. In this case report, we wanted to present a patient with argininemia who was followed up with a diagnosis of cerebral palsy for a long time. Early diagnosis, restricted protein and arginine diet are life-saving in this disease. Argininemia should be kept in mind in patients with unexplained neuromotor retardation.

Keywords: Argininemia, urea cycle disorders, cerebral palsy

\section{Introduction}

Cerebral palsy (CP) is the most common lifelong developmental disorder of childhood affecting movement and posture. CP is a non-progressive, permanent loss of motor function, posture and movement disorder which develops as a result of a developing fetus and lesion or injury in the brain in the first months of life. Motor retardation can often be accompanied by sensory, cognitive, behavioral disorders, epilepsy, and secondary musculoskeletal

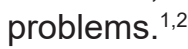

Genetic and metabolic diseases may present with clinical features similar to the CP phenotype. ${ }^{3}$ It is especially important to screen for treatable metabolic diseases. Some 
of these metabolic diseases are urea cycle disorders (UCD), Glucose transporter 1 deficiency syndrome, monoamine neurotransmitter deficiency, biotinidase deficiency, mitochondrial diseases and organic aciduria. Ammonia, lactate, plasma/urine amino acid analysis, tandem mass spectrometry, urine organic acid analysis, cerebrospinal fluid examination are important in screening these diseases.

Ammonia is a toxic substance that occurs as a result of the catabolism of proteins in living things. Hyperammonemia can be mentioned when the plasma ammonia level is $>50 \mu \mathrm{mol} / \mathrm{L}$ (in newborns $>100$ $\mu \mathrm{mol} / \mathrm{L})$. Regardless of the underlying cause, if hyperammonaemia is not treated early and effectively, irreversible brain damage occurs. ${ }^{4,5}$ The most common genetic cause of hyperammonemia in infants is UCD.

The removal of ammonia from the body by converting it into urea with various enzymes in the liver is called the urea cycle. It was first described by Krebsand Henseleit in 1932. Deficiencies of enzymes involved in the urea cycle cause hyperammonemia. Decreased Arginase 1 (ARG1) enzyme activity is blamed for argininemia. This enzyme takes part in the last step of the cycle and provides the conversion of arginine to urea and ornithine..$^{6,7}$

The estimated prevalence of UCD is $1: 35000$ live births. UCD are inherited autosomal recessively, except for ornithine transcarbamylase deficiency (x-linked). Urea cycle enzyme deficiencies usually show symptoms in the first days of life with the intake of protein foods. The main symptoms and signs of hyperammonemia in the neonatal period; refusal to feed, vomiting, tachypnea, convulsion, marked lethargy, stupor and coma. If appropriate treatment is not initiated, patients will rapidly deteriorate and will be lost with cardiovascular collapse, respiratory failure and renal failure..$^{5,8-10}$

This case was presented to draw attention to the case of argininemia, which was followed up with a diagnosis of cerebral palsy for a long time and lost the chance of early diagnosis.

\section{Case}

Thirty two years old male patient presented with complaints of inability to walk, speak, and seizures. $\mathrm{He}$ was referred to our outpatient clinic by the adult neurology department with a pre-diagnosis of metabolic disease. The patient, whose neuromotor development was compatible with his peers until the age of seven, was impaired in walking and then speaking from this age. When the patient was fourteen years old, his speech stopped completely. He was wheelchair dependent when he applied to our outpatient clinic. It was also learned that the patient used valproic acid for epileptic seizures that started three years ago.

Although the birthweight of the patient was unknown, it was learned that he was born at term, cried and had no cyanosis. It was reported that his walking and talking were on time. There was no consanguinity between the parents. It was learned that there was no family member with similar complaints.
The weight: $26 \mathrm{~kg}(<3 p)$, height: $125 \mathrm{~cm}(<3 p)$ percentiles of the patient were found to be extremely low. His head circumfrence: $56 \mathrm{~cm}(16 \mathrm{p})$ was normal. Vital signs were stable. In the physical examination of the patient, he was conscious and non-cooperative. Generalized hypertonicity was noted, along with an extremely weak body structure. There were flexion contractures affecting all four extremities (Figure 1). Therefore, deep tendon reflexes, clonus and babinski could not be evaluated clearly. No hepatomegaly was detected in the abdominal examination. It was normal in other system examinations.
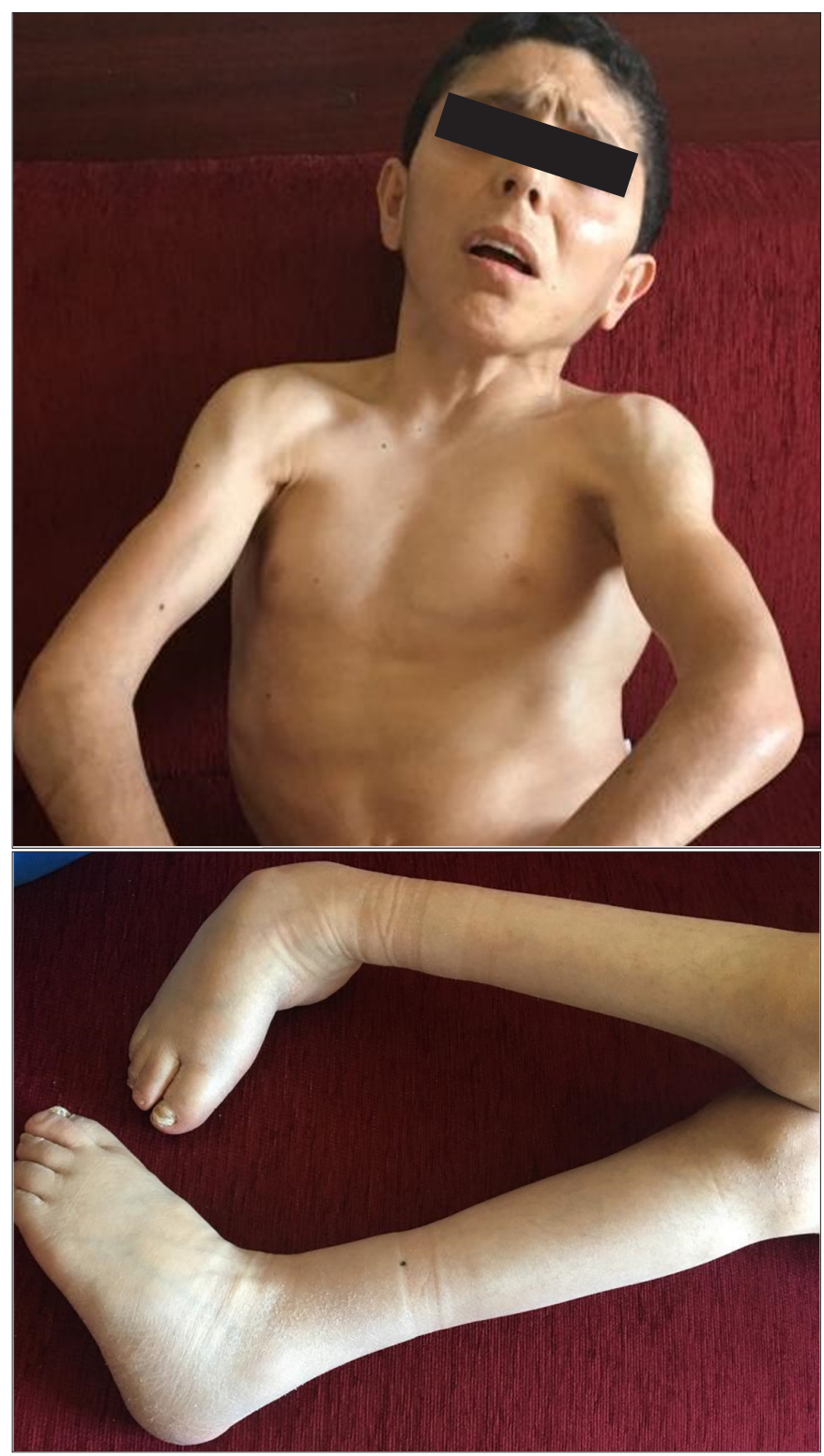

Figure 1. Bilateral spastic paraplegia view of the patient with argininemia

In the basal laboratory tests of the patient, hemogram, thyroid function tests, vitamin B12 and folic acid levels were normal. In other biochemical tests, increased ALT: $115 \mathrm{U} / \mathrm{L}$ (0-41) level and normal range AST: $37 \mathrm{U} / \mathrm{L}(0-$ 40) and CK: 162 U/L (40-170) were detected. Serum valproate level was not measured. In the metabolic tests of the patient, ammonia: $154 \mu \mathrm{mol} / \mathrm{L}(\mathrm{N}: 50-80)$ level was found to be high. It was also observed that arginine levels were significantly increased in plasma and urine amino acid analysis (Table 1). 
Table 1.

His metabolic test results show high levels of arginine in tandem MS and plasma/urine amino acid analysis.

\begin{tabular}{|c|c|}
\hline $\begin{array}{l}\text { Tandem MS } \\
\text { (umol/l) }\end{array}$ & Arginine 477 (6-60) \\
\hline $\begin{array}{l}\text { Tandem Acyl } \\
\text { Carnitine analysis }\end{array}$ & Normal \\
\hline $\begin{array}{l}\text { Plasma amino } \\
\text { acid analysis } \\
(\mathrm{nmol} / \mathrm{ml})\end{array}$ & $\begin{array}{l}\text { Alanine } 141 \text { (200-483), Proline } 66 \text { (104-383), } \\
\text { Isoleucine } 15(34-98), \text { Threonine } 43(67-198) \text {, } \\
\text { Leucine } 35(73-182), \text { Tryptophan } 23(40-91) \text {, } \\
\text { Lysine } 59(119-233), \text { Tyrosine } 30(38-96), \\
\text { Phenylalanine } 28(40-74) \text {, Valine } 56(132-313) \text {, } \\
\text { Arginine } 650 \text { (43-407) }\end{array}$ \\
\hline $\begin{array}{l}\text { Urine amino } \\
\text { acid analysis } \\
\text { (mmol/molkre) }\end{array}$ & Sitrulin $4(0-2)$, Ornitin $13(0-4)$, Arginine $55(0-5)$ \\
\hline $\begin{array}{l}\text { Urine organic } \\
\text { acid analysis }\end{array}$ & Normal \\
\hline
\end{tabular}

In the cranial magnetic resonance imaging of the patient, dilatation in the third and lateral ventricles with frontoparietal region were detected in atrophic appearance (Figure 2). A left-facing scoliosis deformity was observed on chest tomography, other structures were normal. There was extremely scoliosis in the direct X-ray (Figure 3). Multifocal epileptic activity disorder was observed in the electroencephalogram examination. Eye examination was normal.
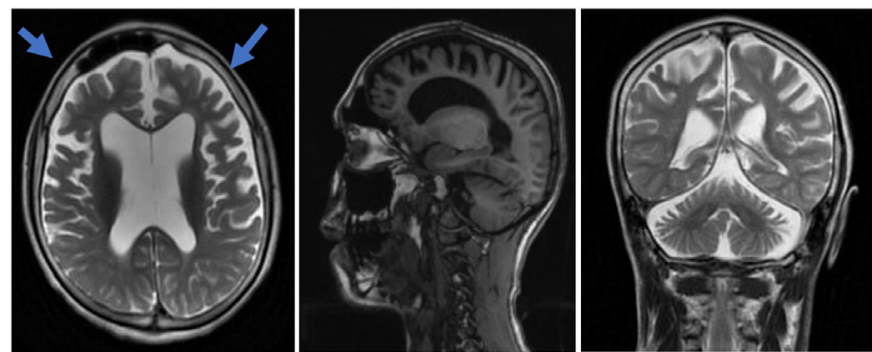

Figure 2. Cranial MR images of the patient with argininemia; significant atrophy in frontoparietal regions of the brain
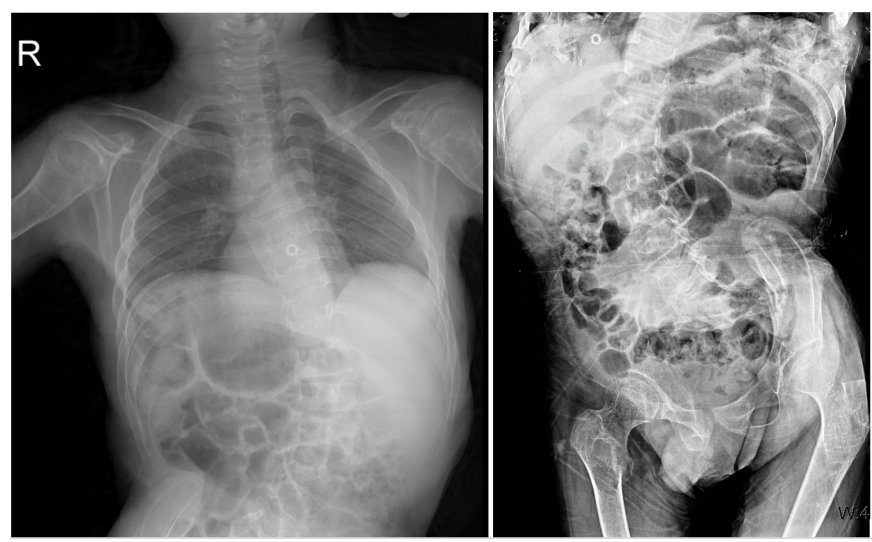

Figure 3. Excessive scoliosis appearance was detected in the X-ray image of the patient

A homozygous mutation in the ARG1 gene c.703 707del (p.Gly235ArgfsTer20) was detected in the genetic examination requested to confirm the diagnosis of argininemia. It was reported that this mutation was considered a pathogenic variant due to the frame shift and early stop codon that was previously described and reported to be associated with the disease.
As a result, our patient was diagnosed with arginemia. Protein and arginine restricted diet was started. Sodium benzoate and sodium phenylbutyrate were initiated for hyperammonemia. In addition, the valproic acid used by the patient for epileptic seizures was replaced with levatiracetam. With the treatment, the patient's liver function tests (AST, ALT) returned to normal. A significant decrease was observed in serum ammonia level (Graphic 1). In the 20-month follow-up, the agitation of our patient decreased significantly and he seemed happier in the control examinations.

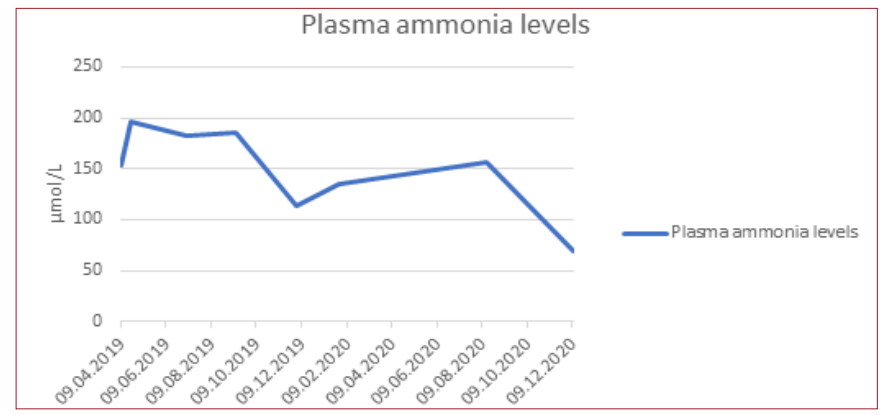

Graphic 1. Ammonia measurements in the argininemia patient's follow-up

\section{Discussion}

The clinical manifestations of UCD can occur at any age, with hyperammonemic crises being frequently triggered by catabolic events, protein overload or certain drugs. Most symptoms are neurological but nonspecific. ${ }^{8}$ Arginase deficiency, which is among this group of diseases, has been reported much less frequently (1:950000). ${ }^{9}$ Rapid-onset hyperammoniemia attacks are not characteristic for argininemia, they follow a slower clinical course. It may often present with growth retardation and pronounced progressive spasticity in the lower extremities. Seizures, loss of intellectual gains, irritability, growth retardation, vomiting and anorexia can be observed. ${ }^{11}$ The arginase enzyme activity of our patient could not be measured, but it was thought that the reason for the slow clinical course may be related with the partial enzyme deficiency.

In the literature, cases with CP findings and diagnosed with argininemia have been reported. In 2020, four years old boy of a Turkish family with psychomotor retardation and walking difficulties were referred to our clinic with the diagnosis of cerebral palsy. In the genetic analysis, the diagnosis of argininemia was confirmed by detecting the homozygous novel mutation in the ARG1 gene. ${ }^{12} \mathrm{~A}$ Korean case presented with attention deficit hyperactivity symtomps and progressive fingertip walking and was diagnosed at the age of eleven. ${ }^{13}$ In arginase deficiency, arginine and its metabolites (such as guanidoacetate) as well as ammonia are considered to be toxic. ${ }^{8}$ In our case, both ammonia and plasma arginine levels were found to be high (Graphic 1, Graphic 2).

The urea cycle disorder argininemia is caused by a defective ARG1 enzyme resulting from mutations in the ARG1 gene. Brazil, China and Turkey, the most common mutations are clustered geographically (p. Thr134lleu, p. Gly235Arg and p. Arg21) have been identified. An even more severe effect was observed for the mutation 
p. Gly235Arg. ${ }^{15}$ In our patient, in accordance with the literature, homozygous deletion has been detected affecting the p. Gly235Arg region. ${ }^{16}$

In 1979, Synderman et al. reported an argininemia case diagnosed in the neonatal period due to the diagnosis of metabolic disease in one of siblings. Arginine and protein restricted diet was started in the early period. When the age of the patient was 32 months, it was evaluated as physically, neurologically and mentally normal. ${ }^{14}$ In our case, it is seen that the delay in diagnosis is quite long. It is obvious that the neuromotor development of our patient will be better with the chance of diagnosis at an earlier age. However, despite the presence of significant psychomotor retardation, ourpatient's agitation decreased significantly after a protein and arginine restricted diet.

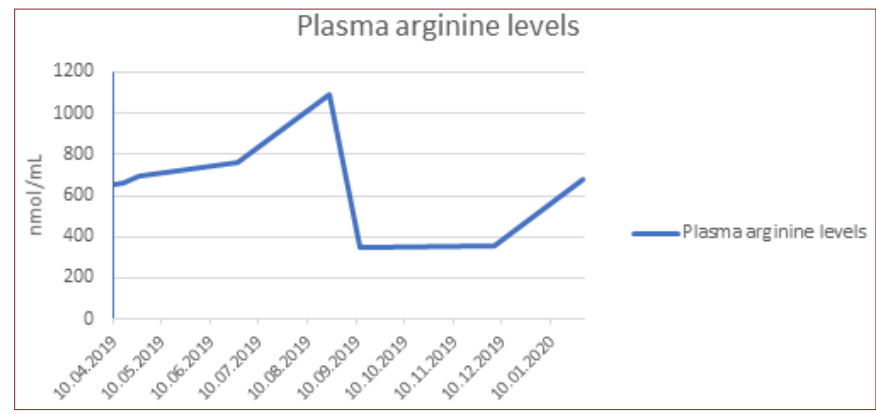

Graphic 2. Arginine measurements in the argininemia patient's followup

\section{Conclusion}

It is important to keep in mind argininemia, especially in cases of unexplained neuromotor retardation and spastic diplegia that occur with age. Favorable results can be obtained in patients who use arginine-restricted diet and ammonia-lowering drugs in the early period of their lives.

Author Contributions: All of the authors declare that they have all participated in the design, execution, and analysis of the paper, and that they have approved the final version.

Conflict of Interest: There are no conflicts of interest in connection with this paper, and the material described is not under publication or consideration for publication elsewhere.

Financial Disclosure: The authors declared that this study has received no financial support
Informed Consent: Written consent was obtained from the patient's parent for the pictures to be used in this article.

Peer-review: Externally peer-reviewed.

\section{References}

1. Piştav Akmeşe, P , Kayhan, N, Mutlu, A. Serebral palsi'li çocuğa sahip olan annelerin aile ortamini algilama düzeylerinin incelenmesi. Toplum ve Sosyal Hizmet 2011;22:105-14. [CrossRef]

2. Serdaroğlu A, Cansu A, Ozkan S, Tezcan S. Prevalence of cerebral palsy in Turkish children between the ages of 2 and 16 years. Dev Med Child Neurol. 2006;48:413-416. [CrossRef]

3. Pearson TS, Pons R, Ghaoui R, Sue CM. Genetic mimics of cerebral palsy. Mov Disord. 2019;34:625-636. [CrossRef]

4. Häberle J. Clinical and biochemical aspects of primary and secondary hyperammonemic disorders. Arch Biochem Biophys. 2013;536:101-108. [CrossRef]

5. Lee B. Urea cycle disorders: Clinical features and diagnosis. Avaliable at: [CrossRef]

6. Rezvani I, Yudkoff M. Urea cycle and Hyperammonemia. Nelson Textbook of Pediatrics Edition 20 Volume 1, 2016:669-675.

7. Haberle J, Rubio V. Disorders of the Urea Cycle and Related Enzymes. Inborn Metabolic Diseases Diagnosis and Treatment 6th Edition, 2016:295-308.

8. Häberle J, Burlina A, Chakrapani A, et al. Suggested guidelines for the diagnosis and management of urea cycle disorders: First revision. J Inherit Metab Dis. 2019;42:1192-1230. [CrossRef]

9. Waisbren SE, Stefanatos AK, Kok TMY, Ozturk-Hismi B. Neuropsychological attributes of urea cycle disorders: Asystematic review of the literature. J Inherit Metab Dis. 2019;42:1176-1191. [CrossRef]

10. Çoskun T. Üre siklusu enzim eksikliği olan hastaların uzun süreli izlemi. Katkı Pediatri Dergisi 1999;20:494-505.

11. Summar ML, Mew NA. Inborn Errors of Metabolism with Hyperammonemia: Urea Cycle Defects and Related Disorders. Pediatr Clin North Am. 2018;65:231-246. [CrossRef]

12. Ustkoyuncu PS, Kendirci M, Gokay S, et al. A Rare Cause of Spasticity and Microcephaly: Argininemia. Turk J Neurol. 2020;26:250-252. [CrossRef]

13. Lee BH, Jin HY, Kim GH, Choi JH, Yoo HW. Argininemia presenting with progressive spastic diplegia. Pediatr Neurol. 2011;44:218220. [CrossRef]

14. Snyderman SE, Sansaricq C, Norton PM, Goldstein F. Argininemia treated from birth. J Pediatr. 1979;9561-63. [CrossRef]

15. Diez-Fernandez C, Rüfenacht V, Gemperle C, Fingerhut R, Häberle J. Mutations and common variants in the human arginase 1 (ARG1) gene: Impact on patients, diagnostics, and protein structure considerations. Hum Mutat. 2018;39:1029-1050. [CrossRef]

16. Yucel H, Kasapkara CS, Akcaboy M, et al. Recurrent hepatic failure and status epilepticus: an uncommon presentation of hyperargininemia. Metab Brain Dis. 2018;33:1775-1778. [CrossRef] 